\title{
STUDY ON THE ETHANOL EXTRACTS OF BULGARIAN WHITE OREGANO (ORIGANUM HERACLEOTICUM L.)
}

\author{
Stanka Baycheva ${ }^{1}$, Krasimira Dobreva ${ }^{1}$ \& Gyurga Mihaylova ${ }^{2}$ \\ ${ }^{1}$ Trakia university, Faculty of Technics and Technologies, \\ 38 Graf Ignatiev str., 8602, Yambol, Bulgaria, e-mail: tania.gt@abv.bg \\ ${ }^{2}$ Trakia University, Faculty of Agriculture \\ Students' campus, 6000, Stara Zagora, Bulgaria
}

\begin{abstract}
The influence of technological parameters - temperature, hydromodule (proportion between row material/solvent $\left(\mathrm{g} / \mathrm{cm}^{3}\right)$ ) and duration of extraction, on the yield and composition of ethanol extracts from Bulgarian white oregano (Origanum heracleoticum L.) whit $70 \%$ ethanol was studied. The yield of extracts and tannins content were defined. The highest yield and content of tannins in ethanol oregano extracts was determined in the following parameters: hydromodule $1: 10,60^{\circ} \mathrm{C}$ and the duration of the process 6 hours.
\end{abstract}

Keywords: white oregano, Origanum heracleoticum L., ethanol extracts, yield, tannins.

\section{INTRODUCTION}

Plant extracts are increasingly entering the food, pharmaceutical and cosmetic industries due to their antimicrobial and antioxidant properties, as well as the increasing negative consumer attitude towards the use of synthetic preservatives. The high concentration of organoleptic ingredients in the extracts determines their richer chemical composition and more pronounced taste and aromatic value compared to the raw materials. They are also bacterially pure, provide stability for the storage of foodstuffs, are easily stored and standardized and are more suitable for use in a variety of foods.

The extracts contain volatile and non-volatile components of the row material, soluble in the selected solvent. They are often used in the production of combined and enriched foods [6]. The extracted volatiles (essential oil) impart aroma to the product, while the non-volatile (carotenoids, steroids, alkaloids, anthocyanins, glycosides, etc.) taste, color, consistency, spiciness and antioxidant properties [11].

The most commonly used extractant in the food industry is ethyl alcohol because of its ability to efficiently extract a number of biologically active substances from plant materials flavonoids, pigments, essential oils, vitamins and tannins [7,9].

The proven antioxidant and anti-inflammatory properties of white oregano extracts due to the content of tannins and phenolic compounds determines the use of the medicinal plant as a prophylactic agent in the fight against cancer and cardiovascular diseases [14,16,18], and for improving the taste and aroma of diets used in patients suffering from gastrointestinal diseases [13].

The purpose of this study is to obtain ethanol extracts from Bulgarian white oregano (wild and cultivated): to study the effect of hydromodule parameters, temperature, and duration of the extraction process on extraction; the content of tannins in the extracts obtained and the degree of their extraction from the starting materials. 


\section{MATERIAL AND METHODS}

The object of the study is Bulgarian white oregano (Origanum heracleoticum L.):

- Wild, growing in flowering phase from the southern slopes of the Eastern Rhodopes (360 $\mathrm{m}$ a.s.l.), the region of Ivaylovgrad, region. Haskovo, Bulgaria at the end of July 2018. The raw material is dried at room temperature without direct sunlight to a moisture content below $10 \%$. Before processing, the raw material is ground by a laboratory mill.

- Cultivated (crumbled leaf), from the land of Parvomay, region Plovdiv, Bulgaria commercially purchased, accompanied by a certificate of physico-chemical and microbiological parameters.

The moisture content of the raw material was determined by azeotropic distillation in a Dean and Stark laboratory apparatus, \%

The content of tannins in the raw material was determined by depleting hot water extraction at reflux and titration of the extract obtained with $0,1 \mathrm{~N} \mathrm{KMnO}_{4}$ at the indigo carmine indicator, \% [4].

Ethyl alcohol (chemically pure for analysis) at a concentration of $70 \%$ was used as the solvent for the extraction.

The extraction was carried out as a periodic process without mixing at two hydromodules $1: 8$ and $1: 10$. The effect of technological parameters temperature $\left({ }^{\circ} \mathrm{C}\right)$ and duration $(\mathrm{h})$ on yield of extracts and on the content of tannins was monitored. The values of the investigated technological parameters are selected on the basis of literature data and by preliminary research.

The raw material is separated from the resulting extracts by filtration with a vacuum filter. A rotary vacuum evaporator with a water vacuum pump was used to separate the solvent from the obtained extracts.

The extracts were stored at $4-6^{\circ} \mathrm{C}$ until analysis. They were characterized by the yield and content of tannins. The yields were brought to a completely dry mass and compared with those obtained by depleting extraction at a process temperature of $60{ }^{\circ} \mathrm{C}$. The content of tannins in the extracts is compared with the amount in the raw material.

The technological researches were carried out in the laboratories of the Faculty of Technics and Technologies - Yambol, Bulgaria.

All experiments were performed in triplicate, with the values in the tables and graphs being the arithmetic mean presented with their standard deviation. The obtained data from measurements and calculations were processed in MS Excel ver. 2016 (Microsoft Corp.) at level of significance $\alpha=0,05$.

\section{RESULTS AND DISCUSSION}

\subsection{Quality evaluation of raw materials}

Values obtained in the determination of the moisture content and the content of tannins of the raw materials are presented in Table 1.

Table 1. Moisture and content of tannins in wild and cultivated Bulgarian white oregano

\begin{tabular}{|l|c|c|}
\hline \multicolumn{1}{|c|}{ Parameters } & Values for wild oregano & Values for cultivated oregano \\
\hline Moisture, \% & $6,65 \pm 0,06$ & $5,98 \pm 0,03$ \\
\hline Tannins, \% & $20,59 \pm 0,12$ & $13,84 \pm 0,09$ \\
\hline
\end{tabular}

The low moisture of the investigated white oregano (less than 10\%) is a prerequisite for its longer storage, while preserving its biologically active substances.

A lower amount of tannins was found in the cultivated plant compared to the wild one, due to the fact that only the leaves of cultivated white oregano are processed.

IRTIIE Vol. 7, No. 3, 2019 ISSN 1314-8788 (print), ISSN 1314-8796 (online), doi: 10.15547/artte.2019.03.005 


\section{ARITIE}

Ipplied Researroches in Technics, Technologies and Eductation Journal of the Faculty of Technics and Technologies, Trakia University https://sites.google.com/a/trakia-uni.bg/artte/

\subsection{Extraction of wild white oregano}

The scheme of the conducted studies and the obtained results are presented in Table 2. For comparison of the yields, a depleting extraction of wild oregano was carried out at a temperature of $60{ }^{\circ} \mathrm{C}(43,83 \% \pm 0,07)$.

Table 2. Extraction yield of wild oregano extract

\begin{tabular}{|l|c|c|c|c|}
\hline \multirow{2}{*}{ № } & \multirow{2}{*}{ Temperature, ${ }^{\circ} \mathrm{C}$} & \multirow{2}{*}{ Duration, $\mathrm{h}$} & \multicolumn{2}{|c|}{ Depleting extract yields, \% } \\
\cline { 3 - 5 } & 20 & 2 & $33,65 \pm 0,28$ & $40,50 \pm 0,26$ \\
\hline 1 & 20 & 4 & $42,12 \pm 0,19$ & $44,99 \pm 0,35$ \\
\hline 2 & 20 & 6 & $43,24 \pm 0,29$ & $45,36 \pm 0,38$ \\
\hline 3 & 20 & 24 & $36,57 \pm 0,18$ & $41,87 \pm 0,16$ \\
\hline 4 & 40 & 2 & $43,62 \pm 0,17$ & $53,68 \pm 0,13$ \\
\hline 5 & 40 & 4 & $48,46 \pm 0,15$ & $56,15 \pm 0,03$ \\
\hline 6 & 40 & 6 & $49,03 \pm 0,18$ & $59,09 \pm 0,29$ \\
\hline 7 & 40 & 24 & $46,22 \pm 0,23$ & $54,83 \pm 0,21$ \\
\hline 8 & 60 & 2 & $47,66 \pm 0,34$ & $60,60 \pm 0,37$ \\
\hline 9 & 60 & 4 & $66,14 \pm 0,26$ & $71,85 \pm 0,32$ \\
\hline 10 & 60 & 6 & $71,53 \pm 0,24$ & $73,56 \pm 0,63$ \\
\hline 11 & 60 & 24 & $58,25 \pm 0,38$ & $63,61 \pm 0,13$ \\
\hline 12 & & &
\end{tabular}

The effect of temperature and extraction duration is shown in Figures 1 and 2. At a temperature of $20^{\circ} \mathrm{C}$, regardless of the duration of the process and the hydromodule used, a relatively low yield was observed.

During extraction for 2 hours, the lowest yields were observed, which was found for all three temperature regimes. At 24-hour extraction, the values are lower than those recorded at the 4- and 6-hour process duration. The ineffectiveness of the 24-hour extraction is due to the equalization of the concentration difference and the flow of desorption processes from the solvent to the plant tissue, as has been found in other materials, reported in available literature sources $[2,3,4,8]$.

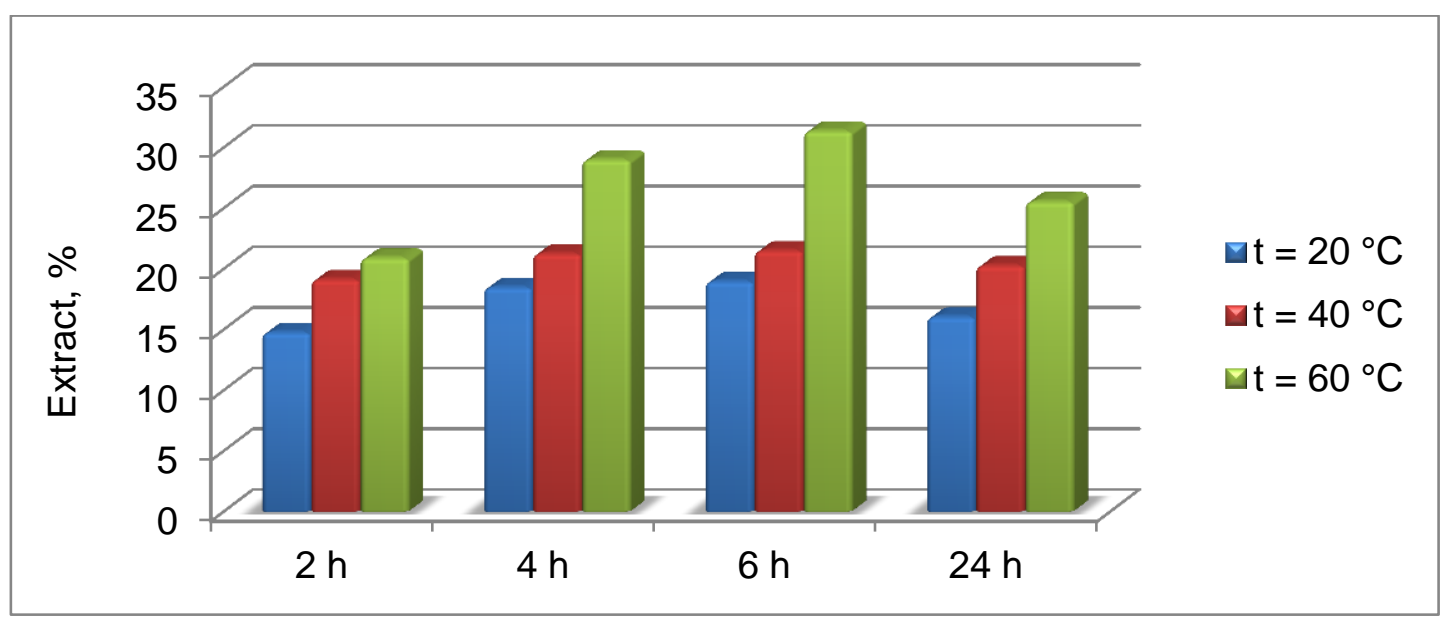

Figure 1. Effect of temperature and duration of extraction at hydromodule 1:8 on extraction of wild white oregano extract

IRTITE Vol. 7, No. 3, 2019 ISSN 1314-8788 (print), ISSN 1314-8796 (online), doi: 10.15547/artte.2019.03.005 


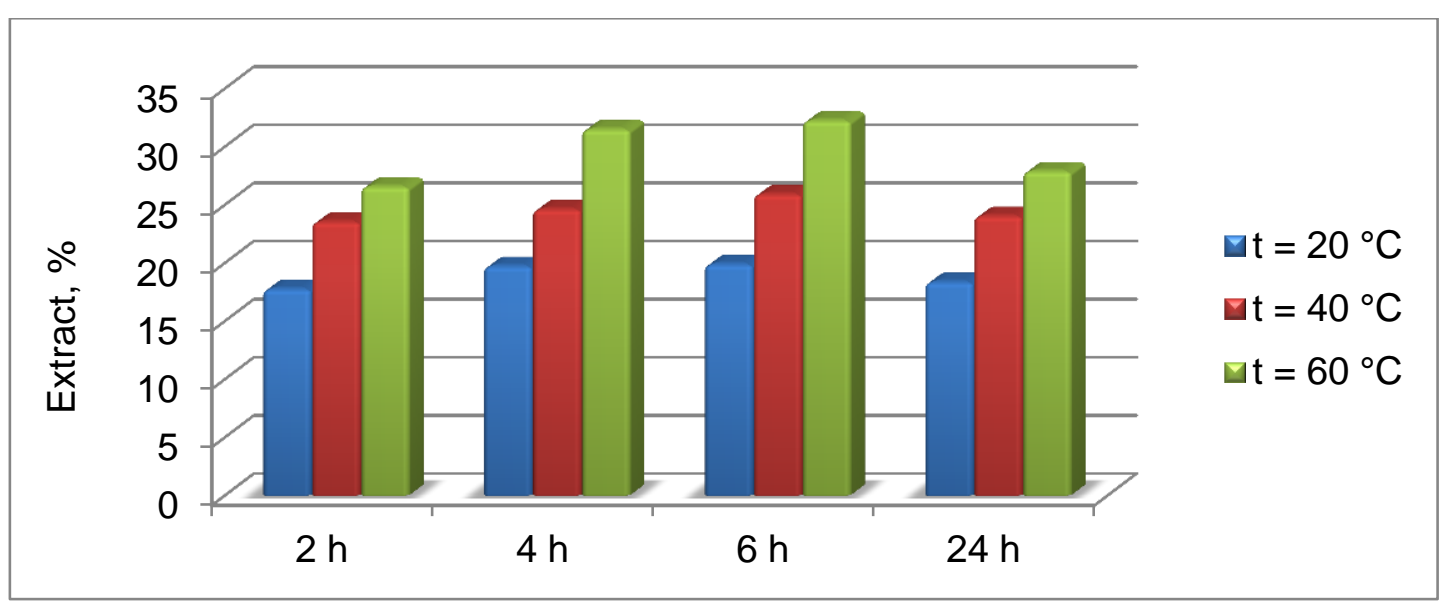

Figure 2. Effect of temperature and duration of extraction at hydromodule 1:10 on extraction of wild white oregano extract

For hydromodule $1: 8$, a lower extract yield was observed compared to the hydromodule $1: 10$ yield, which is valid for the three temperature regimes.

Highest values were reported at 6 hours extraction, hydromodule 1:10 and temperature $60^{\circ} \mathrm{C}$.

The amount of tannins in wild oregano extracts is presented in Table 3 and the degree of their extraction from the raw material - in Figures 3 and 4 . The content of tannins in the extract obtained from depleting extraction of wild white oregano $(19,07 \% \pm 0,11)$ was determined, being $92,62 \%$ of that in the raw material and used for control.

The tannin content of the extracts obtained at $20^{\circ} \mathrm{C}$ and $40{ }^{\circ} \mathrm{C}$ is relatively low and this dependence is also observed in the extraction of the extract.

Table 3. Tannin content of wild oregano extracts

\begin{tabular}{|c|c|c|c|c|}
\hline \multirow{2}{*}{ № } & \multirow{2}{*}{ Temperature, ${ }^{\circ} \mathrm{C}$} & \multirow{2}{*}{ Duration, $\mathrm{h}$} & \multicolumn{2}{|c|}{ Tannin content, \% } \\
\hline & & & Hydromdule 1:8 & Hydromodule 1:10 \\
\hline 1 & 20 & 2 & $4,29 \pm 0,17$ & $5,50 \pm 0,12$ \\
\hline 2 & 20 & 4 & $4,67 \pm 0,22$ & $6,22 \pm 0,29$ \\
\hline 3 & 20 & 6 & $5,55 \pm 0,09$ & $6,88 \pm 0,11$ \\
\hline 4 & 20 & 24 & $4,38 \pm 0,05$ & $6,15 \pm 0,19$ \\
\hline 5 & 40 & 2 & $5,72 \pm 0,08$ & $7,08 \pm 0,16$ \\
\hline 6 & 40 & 4 & $6,26 \pm 0,24$ & $8,05 \pm 0,08$ \\
\hline 7 & 40 & 6 & $6,34 \pm 0,05$ & $8,24 \pm 0,06$ \\
\hline 8 & 40 & 24 & $5,93 \pm 0,04$ & $7,38 \pm 0,12$ \\
\hline 9 & 60 & 2 & $7,65 \pm 0,08$ & $11,30 \pm 0,09$ \\
\hline 10 & 60 & 4 & $10,59 \pm 0,12$ & $11,38 \pm 0,15$ \\
\hline 11 & 60 & 6 & $10,70 \pm 0,05$ & $12,79 \pm 0,07$ \\
\hline 12 & 60 & 24 & $8,85 \pm 0,14$ & $11,61 \pm 0,11$ \\
\hline
\end{tabular}

For the three temperature regimes, irrespective of the extraction time, hydromodule 1:10 is more effective for extraction of extract and tannin content, which is in agreement with the literature [14].

The effect of the duration of the process on the content of tannins retains the same trend as in extraction. The amount of tannins in the extract obtained over 2 hours is significantly lower than that of 4- and 6-hour extraction.

IRTIIE Vol. 7, No. 3, 2019 ISSN 1314-8788 (print), ISSN 1314-8796 (online), doi: 10.15547/artte.2019.03.005 


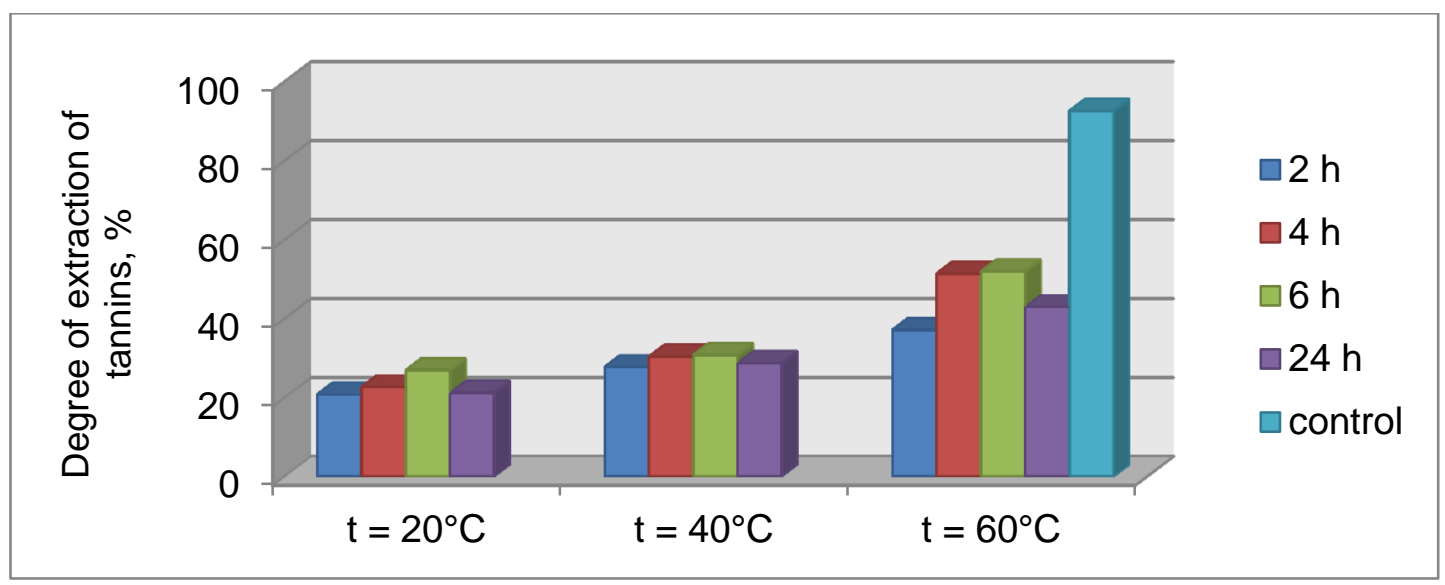

Figure 3. Degree of extraction of tannins in the extraction of wild white oregano hydromodule $1: 8$

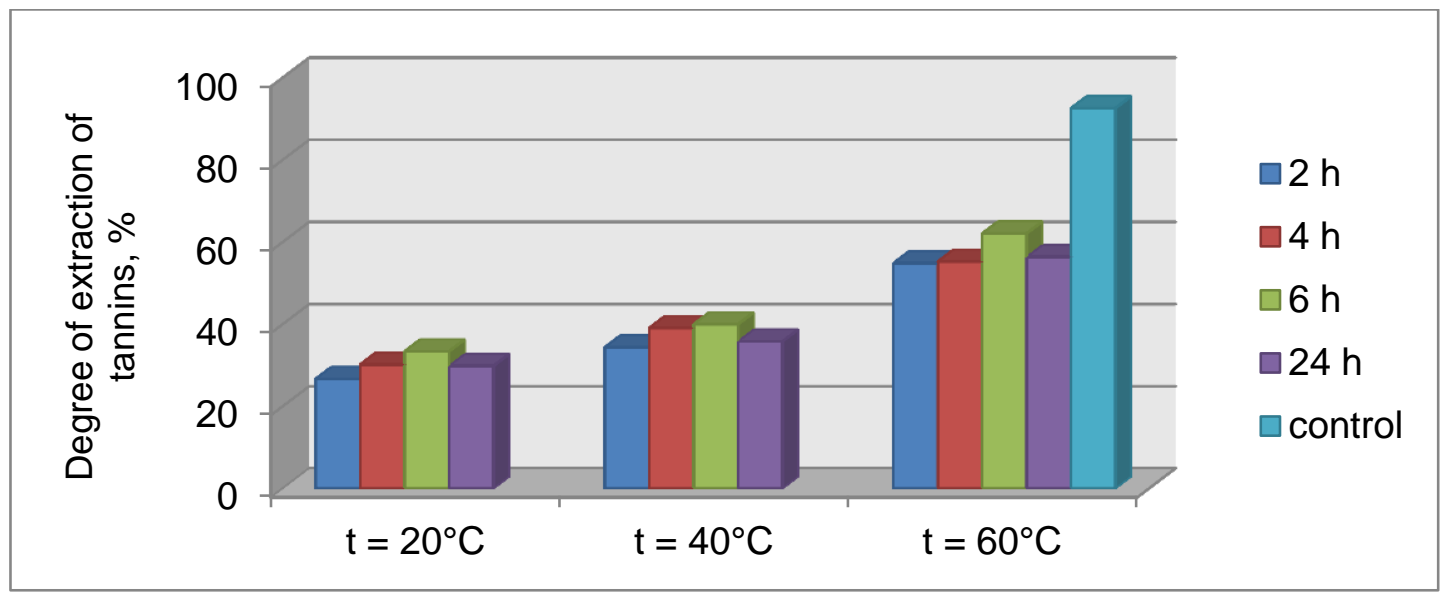

Figure 4. Degree of extraction of tannins in the extraction of wild white oregano hydromodule 1:10

The tannin content of the extracts obtained at the 24-hour extraction is lower than at the 4and 6-hour extracts, regardless of the extraction temperature and the hydromodule used. The degree of extraction of tannins from the raw material at the 24-hour extraction is also lower than the 4- and 6-hour extractions, which confirms its inefficiency.

The data presented show that at $20^{\circ} \mathrm{C}$ and $40{ }^{\circ} \mathrm{C}$ the rate of extraction of tannins from the raw material is relatively low $(20,84-30,79 \%$ at hydromodule $1: 8$ and $26,71-40,02 \%$ at hydromodule $1: 10)$. At $60{ }^{\circ} \mathrm{C}$, extraction of tannins above $50 \%$ was observed, with the highest values reported at hydromodule $1: 10$ and a process duration of 6 hours $(62,12 \%)$.

\subsection{Extraction of cultivated white oregano}

The scheme of the conducted studies and the obtained results are presented in Table 4 . In order to compare the yields, a complete extraction of cultivated white oregano at $60{ }^{\circ} \mathrm{C}$ $(54,04 \% \pm 0,12)$ was performed.

The influence of temperature and duration of extraction is shown in Figures 5 and 6. 


\section{IRTIIE}

Ipplied Researroches in Technics, Technologies and Eductation

Journal of the Faculty of Technics and Technologies, Trakia University https://sites.google.com/a/trakia-uni.bg/artte/

Table 4. Extraction yield of white oregano extract

\begin{tabular}{|l|c|c|c|c|}
\hline \multirow{2}{*}{ № } & \multirow{2}{*}{ Temperature, ${ }^{\circ} \mathrm{C}$} & \multirow{2}{*}{ Duration, $\mathrm{h}$} & \multicolumn{2}{|c|}{ Depleting extract yields, \% } \\
\cline { 3 - 5 } & & 2 & $32,12 \pm 0,15$ & $38,53 \pm 0,07$ \\
\hline 1 & 20 & 4 & $40,54 \pm 0,09$ & $42,93 \pm 0,14$ \\
\hline 2 & 20 & 6 & $41,41 \pm 0,13$ & $45,04 \pm 0,09$ \\
\hline 3 & 20 & 2 & $42,71 \pm 0,09$ & $48,72 \pm 0,11$ \\
\hline 4 & 40 & 4 & $50,15 \pm 0,13$ & $57,38 \pm 0,17$ \\
\hline 5 & 40 & 6 & $53,87 \pm 0,02$ & $59,31 \pm 0,06$ \\
\hline 6 & 40 & 2 & $43,28 \pm 0,14$ & $51,79 \pm 0,44$ \\
\hline 7 & 60 & 4 & $51,24 \pm 0,04$ & $55,72 \pm 0,09$ \\
\hline 8 & 60 & 6 & $54,89 \pm 0,22$ & $61,81 \pm 0,51$ \\
\hline 9 & 60 & & & \\
\hline
\end{tabular}

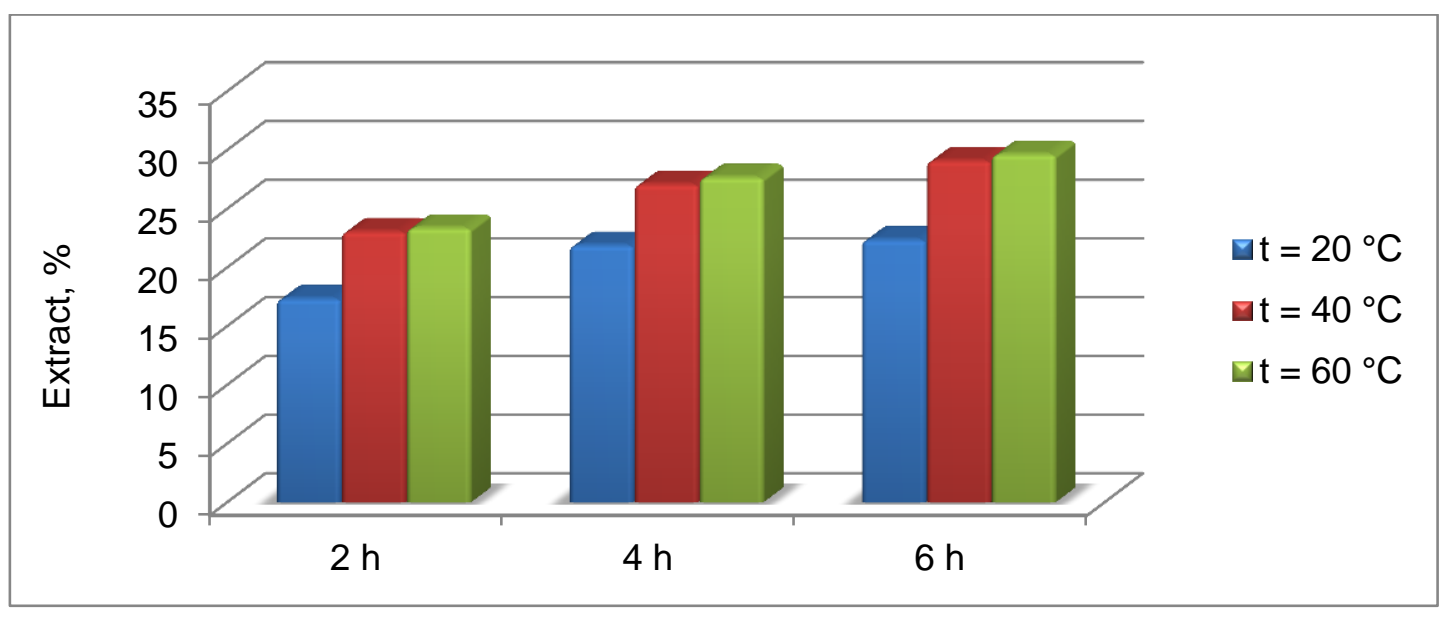

Figure 5. Effect of temperature and duration of extraction at hydromodule 1:8 on the yield of cultivated white oregano extract

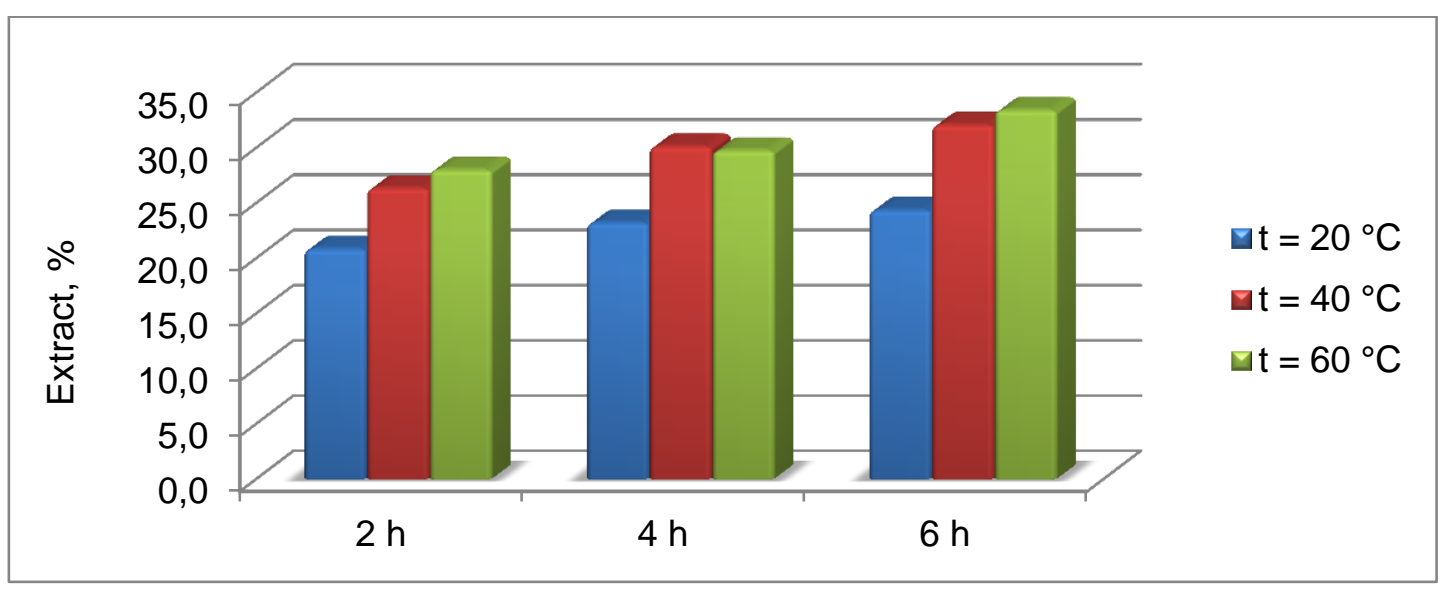

Figure 6. Effect of temperature and duration of extraction at hydromodule 1:10 on the yield of cultivated white oregano extract

IRTIIE Vol. 7, No. 3, 2019 ISSN 1314-8788 (print), ISSN 1314-8796 (online), doi: 10.15547/artte.2019.03.005 


\section{IRITIE}

For both wild-grown and cultured white oregano, extraction over 2 hours is characterized by lower yields than 4- and 6-hour process. Due to the low reported yields of the 24-h extraction of wild white oregano, no such a process was performed on the cultivated one.

The influence of the hydromodule used in the extraction of cultured white oregano retains the same tendency as in the wild-growing - hydromodule 1:10 is more effective than hydromodule 1:8 for the three temperature regimes found in other studies [13].

The extracts obtained were determined by the tannin content. The amount of tannins in the cultivated white oregano extracts is presented in Table 5, and the degree of their extraction from the raw material - in Figures 7 and 8. During the depleting extraction, the content of tannins in the extract obtained $(13,02 \% \pm 0,09)$ was determined, which is $94,08 \%$ of that in the raw material and used for control.

Table 5. Tannin content of cultivated white oregano extracts

\begin{tabular}{|l|c|c|c|c|}
\hline \multirow{2}{*}{ № } & \multirow{2}{*}{ Temperature, ${ }^{\circ} \mathrm{C}$} & \multirow{2}{*}{ Duration, $\mathrm{h}$} & \multicolumn{2}{|c|}{ Tannin content, \% } \\
\cline { 4 - 5 } & & 2 & $4,11 \pm 0,22$ & $4,98 \pm 0,09$ \\
\hline 1 & 20 & 4 & $4,48 \pm 0,13$ & $5,36 \pm 0,22$ \\
\hline 2 & 20 & 6 & $4,86 \pm 0,33$ & $6,02 \pm 0,17$ \\
\hline 3 & 20 & 2 & $5,50 \pm 0,12$ & $7,33 \pm 0,09$ \\
\hline 4 & 40 & 4 & $5,52 \pm 0,25$ & $7,41 \pm 0,21$ \\
\hline 5 & 40 & 6 & $6,37 \pm 0,11$ & $7,95 \pm 0,15$ \\
\hline 6 & 40 & 2 & $5,63 \pm 0,09$ & $7,14 \pm 0,14$ \\
\hline 7 & 60 & 4 & $6,17 \pm 0,12$ & $7,22 \pm 0,26$ \\
\hline 8 & 60 & 6 & $6,62 \pm 0,05$ & $8,01 \pm 0,19$ \\
\hline 9 & 60 & & & \\
\hline
\end{tabular}

In contrast to the wild white oregano, the cultivated has close values for tannin content in the extracts obtained at $40^{\circ} \mathrm{C}$ and $60{ }^{\circ} \mathrm{C}$. The amount of tannins in the extracts obtained at a temperature of $20^{\circ} \mathrm{C}$ is lower.

For the three temperature regimes, regardless of the duration of extraction, hydromodule $1: 10$ is more effective in tannin content as well as in wild white oregano.

The duration of extraction also affects the content of tannins. Extraction of tannins above $50 \%$ at 40 and $60{ }^{\circ} \mathrm{C}$ was observed, hydromodule $1: 10$ with the highest values being reported at $60^{\circ} \mathrm{C}$, hydromodule $1: 10$ and process duration 6 hours $(57,88 \%)$.

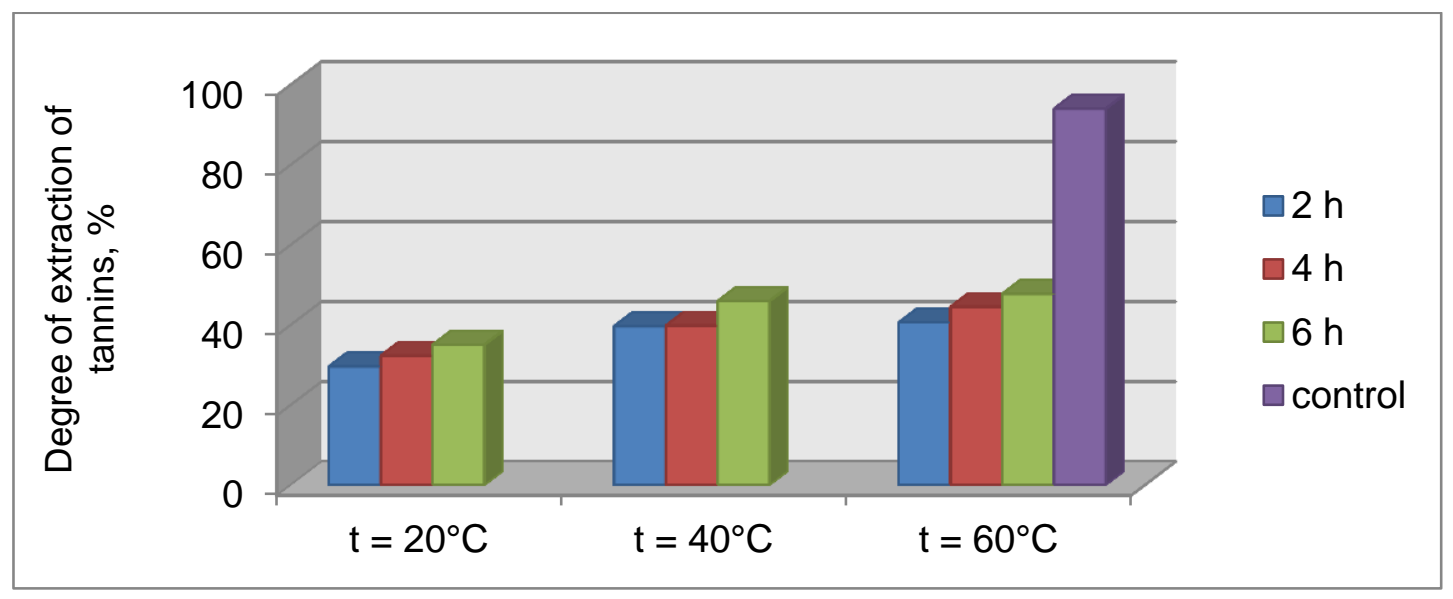

Figure 7. Degree of extraction of tannins in the extraction of cultivated white oregano hydromodule $1: 8$ 


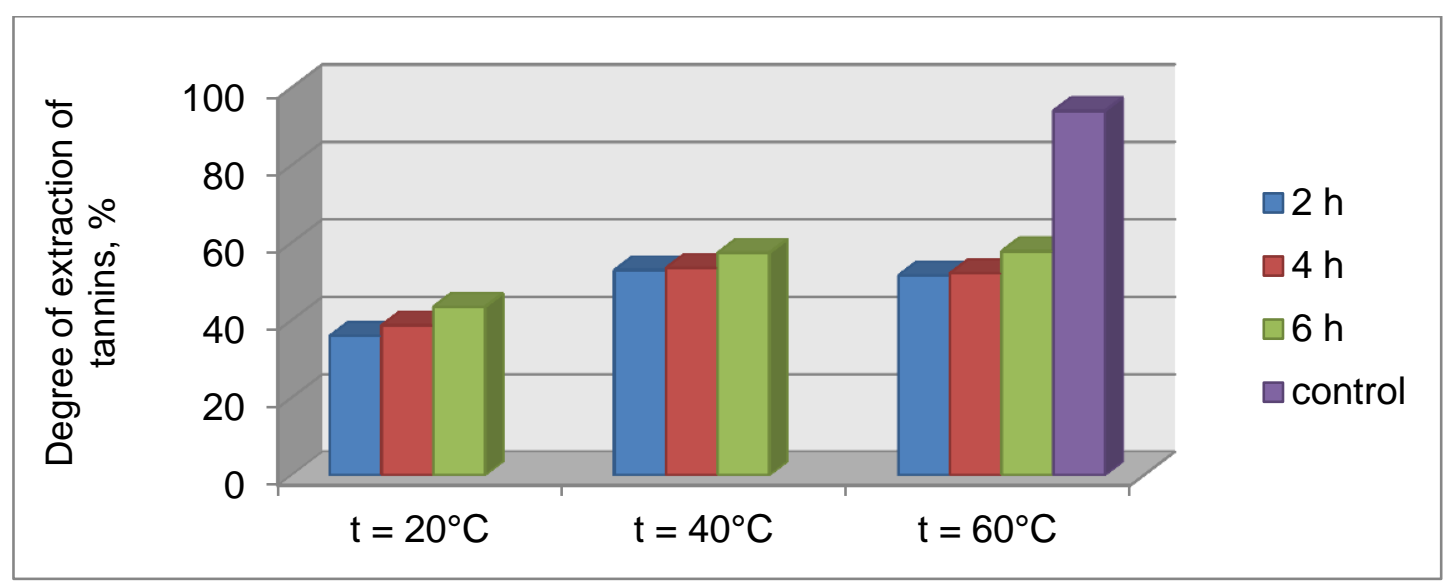

Figure 8. Degree of extraction of tannins in the extractionof cultivated white oregano hydromodule 1:10

\section{CONCLUSION}

The Bulgarian white oregano contains a high amount of tannins $(13,84-20,59 \%)$ and is a suitable raw material for the preparation of ethanol extracts.

The highest yield of extraction of wild and cultivated Bulgarian white oregano with $70 \%$ ethyl alcohol is obtained at a process temperature of $60^{\circ} \mathrm{C}$, hydromodule $1: 10$ and a duration of 6 hours. The temperature of the process is more influenced by the extraction of the extract than its duration.

Extracts obtained at a temperature of $60^{\circ} \mathrm{C}$, hydromodule $1: 10$ and a process duration of 6 hours have the highest content of tannins, and at these parameters they are extracted most completely from the starting material. The extraction of tannins is proportional to the increase in the extraction temperature and the length of the process.

\section{ACKNOWLEDGEMENTS}

The present research is the result of the work on a research project 5FTT/2016 "Technological studies for obtaining of aromatic products from spices", funded by the Science Fund of the Ministry of Education and Science and the Thracian University.

\section{REFERENCES}

[1] Atanasova T., Merdzhanov P. \& Stoyanova A. (2016). Laboratory manual for essential oil technology. UFT Academic Publishing House, Plovdiv. (in Bulgarian).

[2] Balinova-Tsvetkova A. (1980). Investigation of the influence of some technological factors on the yield and quality of lavender concretes. Thesis, DSc, VIHVP, Plovdiv. (in Bulgarian).

[3] Georgiev E. (1995). Technology of natural and synthetic aromatic products. Zemizdat Publishing House, Sofia. (in Bulgarian).

[4] State Pharmacopoeia of the USSR, XI. (1990). Publishing house "Medicine", Moscow, 286. (in Russian).

[5] Dobreva K. (2009). Technological studies of spice extracts - black pepper (Piper nigrum L.), cumin (Cuminum cyminum L.) and coriander (Coriandrum sativum L.). Dissertation, Doctor, UFT, Plovdiv. (in Bulgarian). 


\section{AR'TIE Ipplied Reseirrches in Technics, Technologies and Educition Journal of the Faculty of Technics and Technologies, Trakia University https://sites.google.com/a/trakia-uni.bg/artte/}

[6] Domaretsky V. (1990). Production of concentrates, extracts and soft drinks. Directory, Kiev, 250. (in Russian).

[7] Mustafina A. (1999). Development of technology for fruit and berry extracts with a view to their use in the production of dairy products. Abstract. Dis, DSc, Kemerovo, pp.18 (in Russian).

[8] Taneva I. (2015). Technological studies of rosehip extracts (Rosa canina L.). PhD Thesis, UFT, Plovdiv. (in Bulgarian).

[9] Ushanova V., Voronin V., Repyakh S. (2001). Investigation of the influence of components of medicinal plant material on the composition of extracts. Chemistry of Plant Raw Materials, No. 3, 105-110. (in Rusian).

[10] Beddows C., Jagait C. \& Kelly M. (2000). Preservation of alpha-tocopherol in sunflower oil by herbs and spices. Internatonal Journal of Food Sciences and Nutrition, Vol. 51, No. 5, (2000), pp. 327-339.

[11] Boelens M. \& Boeleus H. (2000). The Chemical and Sensory Evaluation of Edible Oleoresins. Perfumer and Flavorist, Vol. 25, No. 4, (2000), pp. 10-23.

[12] Boroski M., Giroux H., Sabik H., Petit H., Visentainer J., Matumoto-Pintro P. \& Britten M. (2012). Use of oregano extract and oregano essential oil as antioxidants in functional dairy beverage formulations. Lebensmittel Wissenschaft und Technologie - Food Science and Technology, Vol. 47, No. 1, (2012), pp. 167-174.

[13] Chrpova D., Kourimska L., Gordon M., Hermanova V., Roubickova I. \& Panek J. (2010). Antioxidant activity of selected phenols and herbs used in diets for medical conditions. Czech Journal of Food Sciences, Vol. 28, No. 4, (2010), pp. 317-325.

[14] Conforti F., Marrelli M., Menichini F., Tundis R., Statti G., Solimene U. \& Menichini F. (2011). Chemical composition and protective effect of oregano (Origanum heracleoticum L.) ethanolic extract on oxidative damage and on inhibition of NO in LPS-stimulated RAW 264.7 macrophages. Journal of Enzyme Inhibition and Medicinal Chemistry, Vol. 26, No. 3, (2011), pp. 404-411.

[15] Economou K., Oreopoulou V. \& Thomopoulos C. (1991). Antioxidant activity of some plant extracts of the family Labiatae. Journal of the American Oil Chemists Society, Vol. 68, No. 2, (1991), pp. 109-113.

[16] Exarchou V., Nenadis N., Tsimidou M., Gerothanassis I., Troganis A. \& Boskou D. (2002). Antioxidant activities and phenolic composition of extracts from Greek oregano. Journal of Agricultural and Food Chemistry, Vol. 50, No. 19, (2002), pp. 5294-5299.

[17] Martinez-Tome M., Jimenez A., Ruggieri S., Frega N., Strabbioli R. \& Murcia M. (2001). Antioxidant properties of Mediterranean spices compared with common food additives. Journal of Food Protection, Vol. 64, No. 9, (2001), pp. 1412-1419.

[18] Zheng W. \& Wang S. (2001). Antioxidant activity and phenolic compounds in selected herbs. Journal of Agricultural and Food Chemistry, Vol. 49, No. 11, (2001), pp. 51655170 . 